\title{
Research on Improvement of Social Security System Based on Background of Public Finance
}

\author{
Wenjie Yang $^{1}$, Wei Wei ${ }^{2}$ \\ ${ }^{1}$ School of Management, Hebei University, Baoding, 071002, China \\ ${ }^{2}$ The Central Instituite for Correctional Police, Baoding, 071000, China
}

Keywords: Public finance. Social security. Method study

\begin{abstract}
The change of fiscal policies is an important means for economic intervention of the state. The government should implement positive fiscal policies and expand fiscal expenditures. For the rationality of fiscal expenditures, a complete public financial system must be established. The establishment of public financial system aims at providing adequate public products or services to meet public needs. Social security system is an important part of public financial system. Currently, it is urgent to further improve social security system based on the development and stability of China, increase the proportion of social security expenditures in public financial expenditures and increase the input into rural areas.
\end{abstract}

\section{Introduction}

After experiencing global financial crisis, the government must conduct macroeconomic control, exert the intervention effect of the state on economy and adjust fiscal policies when facing a crisis. Public finance is an important part. The basic function of public finance is to meet social public needs. A complete social security system is an important social public need. Establishing social security system, increasing social security expenditures and making public finance fully come into play under conditions of socialist market economy has significant meaning for further promoting the reform of economic structure, ensuring the stability and harmony of the society, improving the living standard of people and comprehensively building well-off society.

\section{Status of Chinese social security system}

\section{Narrow coverage of social security and inadequate funding}

Currently, three important insurances - unemployment insurance, medical insurance and retirement insurance are only popularized in the government and state-owned enterprises and public institutions. Other non-state-owned units do not have these insurances. Currently, migrant workers in cities i.e. peasant-workers need social concern most and are neglected most easily. According to the statistical result in 2012, the number of peasant-workers in China reached 0.26 billion and they are main labor forces in the construction of China but always lack social security. Though basic endowment insurance has made great progress in standard management, hidden conflicts are exposed after the implementation of full payment and allocation and socialized issuance and the situation of expenditure beyond income of funds has been increasingly severe. In pilot regions, new laid-off workers no longer enter re-employment service center in principle and they directly get unemployment insurance benefits. Unemployment insurance fund and re-employment work pressure increase. It is required to continue to guarantee the basic life of laid-off workers in detention center. In a period of time, double burdens might aggravate financial pressure. In particular, when the relief of labor relation of employees involves some debt problems, if they are not handled carefully, some unstable factors might occur: comprehensive implementation of basic medical insurance system of urban employees and medicine and health service system reform. Employing units and individuals must pay the fees according to provisions. Medical institutions should establish a normal fiscal compensation mechanism. Civil servants should implement medical aid system. Some new requirements will be made for finance: improve the minimal subsistence guarantee system of urban 
residents, increase the number of people enjoying it and increase fiscal funds etc. All this will bring some new difficulties to the arrangement of financial fund.

\section{Incomplete Chinese social insurance management system}

The overall work of Chinese social insurance management is planned by the State Council and is managed by the administrative department in each province and region respectively. In terms of the subject of management structure, state-owned enterprises and collective enterprises are managed by the Ministry of Labor uniformly. Employees of organs and units and public institutions are managed by the Ministry of Personnel. In terms of function division, China adopts the mode of combination of unified and centralized central management and decentralized management of each local region. As central authority, the State Council is responsible for legislation and institution setting of units in area, arrange executive staff and conduct supervision in daily work. It is not responsible for the management of funds and employees. Management organizations in each region are responsible for implementing central policies and can arrange the allocation of funds and establish corresponding rules and regulations according to the specific situation of regional development. Administrative departments in grass-roots units and enterprises only need to carry out work according to policies, manage the allocation of funds, take charge of the use and raising of funds and contact with grass-roots employees in work to make adjustments according to actual feedback in management. Such management mode with clear hierarchy does not have unified planning in the overall operation of policies and lack pertinent institutions in supervision and management. It is adverse to the exertion of functions of public security system.

\section{Less sources of social security fund and irrational usage mode}

To establish a complete social security system, there must be stable sources of social security fund. Therefore, it is required to establish a stable and diversified social security fund source system. Sources of Chinese social security are mainly the government, enterprises and individuals. This mode has certain guarantee in fund raising. However, the source of fund is single. It is necessary to increase channels of fund raising. Certain social security tax[1] can be collected according to income level with tax as lever. Such mode has long-term practical experience in many western countries. With tax as channel, it is conducive to reducing the gap of wealth, maintaining national stability, reducing burdens of the state and enterprises and exerting the function of social security better. The management of social security funds has many shortages. A complete operation system is not established in fund raising management, operation mode and supervision balance. Phenomena of nonstandard and non-transparent operation occur in the process of fund allocation and use. Fund abuse easily occurs due to the lack of supervision management, which impairs interests of the state and tax payers.

\section{Adjustment of Chinese fiscal expenditure structure}

Currently, China adheres to Scientific Outlook on Development, constantly deepens reform and opening up, accelerates the construction of harmonious socialist society, adheres to people-oriented policy, promotes joint and harmonious development of people and society, combines economic construction and the improvement of life quality of people and takes sustainable development route; strengthens and accelerates the development of harmonious society, pays attention to joint development of economic construction and society, establishes various policies promoting social harmony and stability in the process of economic construction, combines objectives of social development and economic development, drives the constant enrichment of social material wealth and the improvement of life standard of people and creates conditions for economic development with a good social environment. This requires strengthening the harmony when manpower resources and social resources are used, promoting sustainable development of the society with efficiently used social resources and high-quality manpower resources, realizing mutual promotion during economic development and jointly promoting social development in the establishment of policies. This development mode reflects the superiority of socialist society and promotes the resolution of social wealth distribution problem. 
The adjustment of fiscal policy is the adjustment of distribution relation. Improving social wealth distribution through the change of fiscal policy is an important means for the government to perform its functions. Currently, China is in the critical period of function transformation of Chinese government. Since the reform and opening up, China has made great achievements in economic development but has some problems in social stability. Therefore, paying attention to the transformation of government function from economy to public service becomes the key point of the current work. The government is required to put emphasis of work on the improvement of public service quality, satisfaction of public demands and acceleration of construction and improvement of social security system. China changes the emphasis in fiscal policy, pays attention to the improvement of quality instead of the increase of quantity, improves the direction and structure of input, puts the main foothold of solving problems on income distribution relation, increases the proportion of social security expenditure in fiscal expenditures in gross, strengthens the input of the government into social security and focuses on exerting public service function of the government and promoting joint development of other aspects based on harmonious social development. Economic development stage theory o fAmerican economists Rostow and Musgrave reveals the general law of fiscal expenditure structural adjustment: in the take-off stage, government function is mainly economic service and it focuses on providing the investment of social infrastructure as material base of economic take-off; as economy reaches mature stage, government function gradually expands to social public service.

According to requirements of development route established currently and the current state of irrational fiscal expenditure structure, the basic method of adjusting public fiscal expenditure proportion is: to increase the expenditure in promoting social balanced development, focus on increasing the capital investment into rural construction, establish complete social security system and comprehensively improve the coverage and ability of security. Invested funds are used for education, special care and social welfare.

\section{Establishment of social security system under public finance}

\section{Fund supply of social security}

The future fiscal work will focus on strengthening the reform of fiscal expenditure management, establishing public fiscal organization structure meeting requirements of current market economic development, integrating economic construction and public utilities, changing traditional working concept in the process of vigorously developing productive forces and constantly improving fiscal income and setting up a public financial operation mode meeting national conditions with economy driving social harmony; improving the investment proportion of fiscal expenditure, reducing profitable investment expenditure, saving administrative expenditure, establishing expenditure restraint plan and greatly improving funding in social public needs and social security. The main problem in real social security is that funding amount falls behind the rising speed of needs. This requires us to adjust expenditure structure according to requirements of public finance, take social security expenditure as one of the key points in expenditure currently and endeavor to increase social security expenditure budget. Social security fee and financial allocation funds are two main capital sources of social security expenditure. If there are stable capital sources and wide capital source coverage, we can increase aggregate income and reduce the financial pressure of the state. The ultimate goal of work is to ensure social fiscal income. Capital investment should be reasonable and timely. It is required to improve fund raising mechanism and increase the volume of expenditures in national financial budget. In regions with good economic development, it is also required to guarantee a complete social security fund system and ensure the reasonable growth of social security fiscal expenditure budget.

\section{Medical and health system reform}

Currently, the State Council and provincial and municipal governments have issued a policy document about basic medical insurance of urban employees, medical and health service system and pharmaceutical production and circulation system reform. The document has specified the key 
emphasis in work for grass-roots medical and health system construction. It is required to establish policies for medical and health system reform based on local practical situation according to the guiding spirit of the document, constantly deepen medical insurance system reform, implement financial aid policy for health and two-way management of hospital drug income and expenses, reasonably use capitals invested into medical insurance by public finance, ensure the coverage of medical insurance and guarantee rural areas and economically underdeveloped areas.

\section{Strengthen social security funds management}

The management of financial fund is an important function of financial sector at each level. To establish and improve social security system, financial department must carry out management work of social security funds well, reform budget management system, make fund use plan and budget in each department, take control in receipt and payment system of national treasury with the method of setting up an account respectively and make clear the flow of each fund. The government should purchase social public goods intensively, strengthen the control and supervision over the process of purchasing medical and health equipment and relief supplies and conduct fiscal appropriation reasonably.

\section{Research on the establishment of social security system}

Currently, we are facing a new situation in the establishment of social security system. For the change of situation, it is necessary to understand the direction of change of situation in time. In-depth understanding of the practical situation is a main approach for establishing reasonable policy measures. Fiscal administration staff of social security at each level should understand the importance of investigating the practical situation at the grass-roots level, arrange the working time well, carry out purposeful and pertinent investigation and research at the grass-roots level and realize that policies come from the reality and serve people. The emphasis in work can be put on the following aspects: old-age pension, re-employment of laid-off workers in state-owned enterprises, subsistence allowances of urban residents, popularization of medical care insurance system, establishment of special care guarantee system and collection of social security fee.

\section{Increase the input into rural areas in public finance}

According to statistical data, incomes of urban and rural residents show a constant rising trend on the whole but have a great gap. In 2012, total incomes per capita of urban residents were 26,959 Yuan and net incomes per capita of rural residents were 7917 Yuan. In the transitional period of financial system, it is necessary to stop the behavioral momentum of dividing fiscal revenue and expenditure into agriculture and non-agriculture; the support direction of fiscal policy should turn to rural areas. The change of policies aims at feeding rural economy. The formation of "three rural issues" is caused by the policy that the state sacrifies rural economic development in a long period of time in order to accelerate the realization of industrialization and implement the development strategy of supporting city with countryside and supporting industry with agriculture. Therefore, when economic development level increases significantly, the state and government should start to accelerate rural development, increase the financial investment into rural areas, establish and improve social security system in rural areas and strengthen policy support for each industry in rural areas. The deepening of economic system reform requires the reform of rural public service system and establishment of same system in urban and rural areas. It is required to gradually establish a harmonious and unitary urban and rural public service supply system, promote joint development of rural and urban areas and exert the guiding function of fiscal expenditure in the aspect of integrating urban and rural public service supply.

\section{Conclusion}

Meeting social public needs is a main function of public finance. The transformation from national finance to public finance is a great progress in China. Improving social security system and guaranteeing social security expenditure needs is an important function of public finance under conditions of socialist market economy. The establishment and improvement of social security system have important meaning for deepening economic system reform, promoting social stability 
and development and improving the life of the masses. Therefore, it is required to transform fiscal expenditure structure, expand the coverage of public expenditure, establish a complete operating mechanism based on the practical situation in different regions and ensure full exertion of functions of social security system.

\section{References}

[1] Diao Junqiang. Chinese Social Security System: Status and Path Selection [J]. Journal of Yangtze Normal University, 2011 (5).

[2] Feng Yanrong. Discussions on Improvement of Social Security System under Public Finance [J]. Modern Business, 2009(30).

[3] Deng Lina. Research on Social Security System Construction in Current Situation [J]. Science and Wealth, 2013(03).

[4] Zhang Xiaolei, Hang Zheng. Improvement of Social Security System under Public Finance Framework [J]. Journal of Beijing Technology and Business University (Social Sciences Edition), 2008(03).

[5] Li Qin, Zeng Xianying. Public Finance System Construction and Social Security System with Full Coverage [J]. Sea of Learning, 2008(05).

[6] Lu Heping. Role of Public Finance in Establishment of Social Security System Covering Urban and Rural Residents [J]. Review of Economic Research, 2009(18). 